
\title{
S Research Square
}

\section{A study on dose and time-dependent effect of fluoride in rats}

Vakdevi Validandi ( $\nabla$ vaagdevi@gmail.com )

ICMR-National Institute of Nutrition https:// orcid.org/0000-0001-7894-0578

\section{Arjun Khandare}

National Institute of Nutrition

Srinivas Dheeravath

National Institute of Nutrition

SurekaMullapudi Venkata

National Institute of Nutrition

Srinivasu Kurella

National Institute of Nutrition

\section{Sukesh Narayan Sinha}

National Institute of Nutrition

\section{Research Article}

Keywords: Fluoride, Fluorosis, Dose-dependent, Focal fibrosis, Microvacuolation

Posted Date: March 1st, 2022

DOI: https://doi.org/10.21203/rs.3.rs-1387641/v1

License: (c) (1) This work is licensed under a Creative Commons Attribution 4.0 International License. Read Full License 


\section{Abstract}

The purpose of this study was to see the effect of fluoride (F) in Wistar NIN rats in a dose and timedependent manner. Male rats $(\mathrm{n}=36)$ were taken and were randomly divided into six groups (Group I: control, group II: $5 \mathrm{mg} / \mathrm{L}$ F, Group III: $10 \mathrm{mg} / \mathrm{L}$ F, Group IV: $15 \mathrm{mg} / \mathrm{L} \mathrm{F,} \mathrm{Group} \mathrm{V:} 50 \mathrm{mg} / \mathrm{L}$ F and Group VI: $100 \mathrm{mg} / \mathrm{L} F)$. Animals were examined at 3-time points of 30, 60 and 90 days for $F$ toxicity changes. The results indicated that the $\mathrm{F}$ induced dose and time-dependent diet intake, body weight gain, food efficiency ratio, dental fluorosis, urinary, serum, bone and teeth $\mathrm{F}$ levels and histopathological changes in liver and kidney tissue. The significant increase in exposure of $\mathrm{F}$ through water in groups $\mathrm{V}$ and $\mathrm{VI}$ as compared to other groups has shown alterations in their food efficiency ratio, body weight gain, and the significant increase in the urinary and serum $\mathrm{F}$ levels. Histopathology of the kidney showed few dilated tubules in the kidney of group VI compared to all other groups. Whereas histopathology of the liver showed microvacuolation in groups V and VI compared to groups I, II and III. However, there were no significant differences between the organ weight ratios of different organs among all the groups. In conclusion, the dose-dependent effect of $F$ starts at 100, 50 and $15 \mathrm{mg} / \mathrm{L}$ from first, second and third months respectively, however, there were no significant differences in 5 and $10 \mathrm{mg} / \mathrm{L} \mathrm{F}$ groups after 3 months.

\section{Introduction}

Chronic fluoride (F) toxicity is caused by excessive $F(>1.5 \mathrm{mg} / \mathrm{L}$ ) (World Health Organization., 2003) which is endemic in twenty-five countries around the world. In India, fluorosis has been pronounced endemic in 20 of 35 states and union territories (World Health Organization, 2004). Based on the tissue affected, chronic F toxicity is categorized as dental, skeletal and non-skeletal fluorosis. Fluoride is absorbed in the mouth, stomach, lungs, small intestine and skin by passive diffusion (Khandare et al., 2001). Fluorosis, an irreversible disease that affects people of all ages, is a major public health concern globally including in India (Susheela and Bhatnagar,2002).

In India, the concentration of $\mathrm{F}$ range from $0.1-48 \mathrm{mg} / \mathrm{L}$ in different states (Saxena and Sewak, 2015). The risk of developing fluorosis in an individual is minimal if exposed to $0.05 \mathrm{mg} / \mathrm{kg}$ of $\mathrm{F}$ by daily oral ingestion (Watanabe et al., 1997; Wei, 2002). Adults were shown to be fatally poisonous when exposed to $\mathrm{F}$ at doses of $16-64 \mathrm{mg} / \mathrm{kg}$, whereas neonates were found to be harmful at lower levels of $3-16 \mathrm{mg} / \mathrm{kg}$ (Wang and Huang, 1995).

The earlier studies revealed that the excess ingestion of $\mathrm{F}$ amperes nutritional status (Irigoyen-Camacho et al., 2016; Del Carmen et al., 2016; Rugg-Gunn et al., 1997) like stunting (Irigoyen-Camacho et al., 2016; CorreiaSampaio et al., 1999). The effect of $F$ on body weight gain (BWG) is controversial. In F-fed animals, reduced food intake and BWG have been observed (rats, rabbits, hens, claves) (Lohakare et al., 2010; Khandare et al., 2007; Dunipace et al., 1998; Coetze et al., 1997). Other investigations, however, found no difference in BWG in F-fed mice (Balaji et al., 2015; Turner et al., 1997). This discrepancy could be attributable to the different species employed, the dose of $F$, and the length of the study. Fluoride 
exposure causes oxidative stress, which can lead to a reduction in growth and food utilization efficiency (Chen et al., 2013). There are few investigations on the food efficiency ratio (FER), which is an important indicator of the food converted into BWG.

Exposure to $\mathrm{F}$ increased $\mathrm{F}$ content in the organs and tissues (Inkielewicz Krechniak, 2003). In Wistar rats, the exposure to $F$ increased the concentration of $F$ in serum and urine (Inkielewicz Krechniak, 2003; Yu-e Song et al., 2011; Pereira et al., 2013).The exposure to F resulted in histopathological changes in the kidney and liver (KhadarBasha et al., 2014).

There is a paucity of studies in the literature on the nutritional status, urinary $F$, serum $F$ and histopathological changes in the different organs in an $\mathrm{F}$ dose-dependent manner. Hence, different concentrations of $\mathrm{F}$ at different periods were administered to rats in the present study to understand the effective dose and duration of $F$ that would cause $F$ toxicity in rats.

\section{Materials And Methods}

\subsection{Experimental Animals}

One-month-old 36 male Wistar NIN rats weighing $104.95 \pm 7.901 \mathrm{~g}$ (mean \pm SD) were obtained from the National Centre for Laboratory Animal Sciences of the National Institute of Nutrition, Hyderabad, India, and were randomly distributed into 6 groups of 6 animals each and their weight was not significantly different among the groups. The feeding schedule is given in Table 1. All the animals were individually kept in stainless steel cages in a temperature and humidity-controlled environment with a 12-hour light/dark cycle. The Institutional Animal Ethics Committee (P9F/IAEC/NIN/2016/1/VAK/WNIN-38M) approved the animal care and experimental protocols, which were followed.

Table 1

Distribution of animals and feeding schedule of different groups

\begin{tabular}{|clll|}
\hline S.No & Group & N & Treatment \\
\hline 1 & I & 6 & Normal diet and water ad libitum \\
\hline 2 & II & 6 & Fluoride $5 \mathrm{mg} / \mathrm{L}$ in drinking water, normal diet ad libitum \\
\hline 3 & III & 6 & Fluoride $10 \mathrm{mg} / \mathrm{L}$ in drinking water, normal diet ad libitum \\
\hline 4 & IV & 6 & Fluoride $15 \mathrm{mg} / \mathrm{L}$ in drinking water, normal diet ad libitum \\
\hline 5 & V & 6 & Fluoride $50 \mathrm{mg} / \mathrm{L}$ in drinking water, normal diet ad libitum \\
\hline 6 & VI & 6 & Fluoride $100 \mathrm{mg} / \mathrm{L}$ in drinking water, normal diet ad libitum \\
\hline
\end{tabular}

2.2 Food and water intake, body weight gain, FER: Food and water intake, body weight gain and FER were assessed according to an earlier study conducted at our Institute (Shankar et al., 2013).

2.3 Urinary, serum, bone and teeth F: An ion-selective electrode (Model EA 940 Orion) was used to assess urinary and serum fluoride levels (Tusl, 1970). Teeth and bone F were estimated as previously mentioned 
(Singer and Armstrong, 1968).

2.4 Tissue F: The tissue $\mathrm{F}$ levels in the liver and kidney in groups $\mathrm{V}$ and $\mathrm{VI}$ were determined as reported in the earlier study (Inkielewicz Krechniak, 2003).

2.5 Dental fluorosis: Rats were assessed for dental fluorosis at 3rd month.

2.6 Organ weight ratio: The brain, kidney, liver, testis, and heart were all collected and placed individually on pre-marked filter paper after the animals were euthanized by $\mathrm{CO}_{2}$ inhalation. The wet organ weights were immediately weighed using Sartorius balance (BL 600, Germany, the sensitivity of the balance was $0.001 \mathrm{~g}$ ). The individual organ weight was divided by total body weight in grams and multiplied by 100 [(Organ weight/Body weight) $\times 100=\%$ ratio] (Huang et al., 2002).

2.7 Histopathology: Immediately after removal of the brain, kidney, and liver tissues, they were placed in formalin solution and processed for histological examination after staining with hematoxylin and eosin $(\mathrm{H} \& \mathrm{E})$.

\section{Results}

3.1 Food and water intake, body weight gain, FER: There was a significant decrease in food intake in group VI compared to all other groups at 3 months (Fig. 1). The water intake in different groups is given in Fig. 2. A significant decrease in water intake was noticed in group III compared to group I at 3 months. A significant decrease in water intake was noticed in groups V and VI compared to groups I, II, III and IV at 2 and 3 months. The body weight gain and FER in different groups are given in Tables 2 and 3 respectively. There was a significant decrease in body weight gain in Group $V$ and VI compared to groups I, II, III and IV at 1, 2 and 3 months. A significant decrease in FER was observed in group V and VI compared to group I at 1 month. A significant decrease in FER was observed in group IV and $V$ compared to group I at 3 months. 
Table 2

Bodyweight gain of rats at 1,2 and 3 months by different groups.

\begin{tabular}{|c|c|c|c|c|}
\hline Group & $\begin{array}{l}\text { Initial } \\
\text { weight (g) }\end{array}$ & $\begin{array}{l}\text { Body weight gain 1st } \\
\text { month (g) }\end{array}$ & $\begin{array}{l}\text { Body weight gain 2nd } \\
\text { month (g) }\end{array}$ & $\begin{array}{l}\text { Body weight Gain 3rd } \\
\text { month (g) }\end{array}$ \\
\hline I & $\begin{array}{l}101.27 \pm \\
9.34\end{array}$ & $115.07 \pm 21.40$ & $166.53 \pm 29.58$ & $202.40 \pm 34.36$ \\
\hline II & $\begin{array}{l}103.27 \pm \\
6.98\end{array}$ & $115.73 \pm 27.78$ & $172.68 \pm 37.42$ & $202.57 \pm 37.78$ \\
\hline III & $\begin{array}{l}103.98 \pm \\
6.91\end{array}$ & $112.18 \pm 12.51$ & $157.80 \pm 15.52$ & $184.35 \pm 23.15$ \\
\hline IV & $\begin{array}{l}104.78 \pm \\
6.52\end{array}$ & $106.22 \pm 32.88$ & $149.52 \pm 20.38$ & $154.62 \pm 18.00^{\mathrm{a}^{*} \mathrm{~b}^{*}}$ \\
\hline V & $\begin{array}{l}105.38 \pm \\
6.85\end{array}$ & $87.78 \pm 21.76$ & 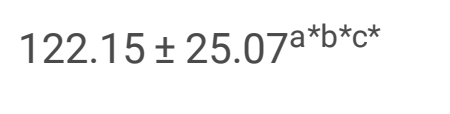 & $132.12 \pm 19.81^{\mathrm{a}^{*} \mathrm{~b}^{*} \mathrm{C}^{*}}$ \\
\hline VI & $\begin{array}{l}106.42 \pm \\
8.65\end{array}$ & 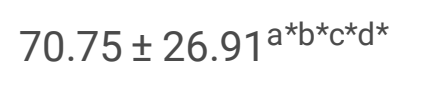 & $85.92 \pm 27.377^{a^{*} b^{*} c^{\star} d^{*} e^{*}}$ & $111.25 \pm 13.16^{a^{* b^{*} c^{*} d^{\star}}}$ \\
\hline \multicolumn{5}{|c|}{$\begin{array}{l}\text { *Statistically significant. a = compared to group } I, b=\text { compared to group II, } c=\text { compared to group III, } \\
d=\text { compared to group IV, } e=\text { compared to group V. Results are expressed as mean } \pm S D ; n=6 \\
\text { rats/group. }\end{array}$} \\
\hline
\end{tabular}

Table 3

Food efficiency ratio (FER) of rats at 1,2 and 3 month in different groups

\begin{tabular}{|c|c|c|c|}
\hline Group & 1 month & 2 month & 3 month \\
\hline I & $0.26 \pm 0.05$ & $0.35 \pm 0.03$ & $0.07 \pm 0.03$ \\
\hline II & $0.22 \pm 0.06$ & $0.32 \pm 0.03$ & $0.05 \pm 0.02$ \\
\hline III & $0.23 \pm 0.03$ & $0.29 \pm 0.04$ & $0.04 \pm 0.02$ \\
\hline IV & $0.23 \pm 0.04$ & $0.32 \pm 0.08$ & $0.01 \pm 0.02^{\mathrm{a}^{*} \mathrm{~b}^{*}}$ \\
\hline V & $0.20 \pm 0.04^{a^{*}}$ & $0.29 \pm 0.05$ & $0.02 \pm 0.03^{a^{*}}$ \\
\hline VI & $0.16 \pm 0.03^{a^{*} b^{*} c^{\star} d^{\star}}$ & $0.28 \pm 0.08 a^{a^{*}}$ & $0.06 \pm 0.05^{d^{*} e^{\star}}$ \\
\hline
\end{tabular}

3.2 Urinary F: The urinary F levels in different groups are given in Fig. 3. A significant increase in urinary $F$ levels in an $\mathrm{F}$ dose and duration-dependent manner was observed.

3.3 Serum F: There was a significant increase in serum F levels in groups II, III, IV, V and VI compared to group I at 1, 2 and 3 months (Fig. 4). There was a significant increase in serum $F$ levels in group $V$ 
compared to groups I, II, III at 1, 2 and 3 months. There was a significant increase in serum F levels in group VI compared to group I, II, III and IV at 1, 2 and 3 months (Fig. 4).

3.4 Bone and teeth F: A dose-dependent increase in the bone and teeth F levels was observed in the study. There was a significant increase in the bone and teeth $\mathrm{F}$ levels in group IV compared to group I. There was a significant increase in bone and teeth F levels in group V and VI compared to groups I, II and III (Fig. 5).

3.5 Liver and kidney F: There was a significant increase in $\mathrm{F}$ accumulation in the liver in group VI compared to group I and group V. An F dose-dependent increase in the accumulation of $F$ in the kidney was observed. However, there is an increase in the $\mathrm{F}$ accumulation in the kidney in group $\mathrm{V}$ and $\mathrm{VI}$ compared to group I but not significant (Table 4). Since there was no significant difference in the tissue $F$ levels in the liver and kidney in group V compared to group I, hence, the tissue F levels in groups II, III and IV were not determined.

3.6 Dental fluorosis: An F dose-dependent increase in the severity of dental fluorosis was observed in the study. The mild dental fluorosis was observed in groups $\mathrm{V}$ and $\mathrm{VI}$ at 3 months which is shown in Fig. 6 .

Table 4

Accumulation of fluoride $(F)$ in the liver and kidney tissue.

\begin{tabular}{|c|c|c|}
\hline Group & Liver F (mg F/g tissue) & Kidney F (mg F/g tissue) \\
\hline I & $0.3167 \pm 0.04320$ & $2.9960 \pm 0.88401$ \\
\hline IV & ND & $2.5800 \pm 0.78823$ \\
\hline V & $0.3100 \pm .03082$ & $3.3400 \pm 0.24980$ \\
\hline $\mathrm{VI}$ & $0.7925 \pm 0.19805^{\mathrm{a}^{*} \mathrm{~b}^{*}}$ & $3.7300 \pm 0.38184$ \\
\hline \multicolumn{3}{|c|}{ ND - Not determined. } \\
\hline
\end{tabular}

3.7 Organ weights: There was no significant difference among all the groups in organ weight ratio for brain, kidney, heart, testes and liver (Fig. 7).

3.8 Histopathology: The dose-dependent changes due to F were studied in the histopathology of the brain, kidney and liver. We did not observe any histopathological changes in the brain among all the groups (Fig. 8). However, in the kidney few focal dilated tubules were observed in group VI compared to all other groups (Fig. 9). In the liver, microvacuolation in 33-66\% was observed in group $V$ compared to groups I, II, III and IV. Microvacuolation in $>90 \%$ liver was observed in group VI compared to group I, II, III and IV (Fig. 10).

\section{Discussion}


The effect of $\mathrm{F}$ in Wistar NIN rats was investigated in this study in a dose and time-dependent manner. The decrease in food intake in Group VI compared to all other groups at 3 months corroborates with the earlier studies (Lohakare et al., 2010; Khandare et al., 2007; Dunipace et al., 1998, Coetze et al., 1997). Fluoride administration reduced body weight increase in rats in a dose and time-dependent manner, according to a previous study (Shanthakumari et al., 2004). Other investigations, however, found no difference in BWG (Turner et al., 1997) in F-fed animals. This inconsistency may be explained by the fact that different species were employed; the dose of $\mathrm{F}$ and also the research was conducted over different time durations. The significant decrease in FER in the group $\mathrm{V}$ and $\mathrm{VI}$ agrees with the earlier studies (Shankar et al., 2013) Reduced FER indicated interference of $F$ with digestion and proper utilization of food. Group V and VI showed an effect on FER from the first month onwards might be due to the highest concentration of $\mathrm{F}$ intake. The significant increase in urinary $\mathrm{F}$ levels in groups II, III, IV, V and VI increased in a dose-dependent manner from 2 months onwards as reported in earlier studies (Inkielewicz Krechniak, 2003; Yu-e Song et al., 2011; Pereira et al., 2013). The significant increase in serum F levels in group II, III, IV, V and $\mathrm{VI}$ compared to group I at 1, 2 and 3 months is in a dose-dependent manner as reported in earlier studies (Inkielewicz Krechniak, 2003; Yu-e Song et al., 2011; Pereira et al., 2013). In the present study, the increase in the severity of dental fluorosis in rats is $\mathrm{F}$ dose-dependent manner. Our results agree with the earlier studies where the F dose-dependent changes in the teeth were observed (Zhang et al., 2016; Hong et al., 2013). Plasma $F$ concentrations in humans range from 1 to $10 \mu \mathrm{mol} / \mathrm{l}$ after long-term intake of 1$10 \mathrm{ppm} F$ in drinking water. Fluorotic alterations can be seen in incisors of rodents after drinking water containing 25-100 ppm fluoride; these doses also enhance the plasma F levels to 3-10 $\mu \mathrm{mol} / \mathrm{l}$, which are similar to those observed to cause fluorosis in humans (Angmar-Mansson and Whiteford, 1990; Angmar-Mansson and Whiteford, 1984). The increase in accumulation of F in bone and teeth in the present study is in a dose-dependent manner and is in concurrence with the earlier reports (Liu et al., 2014; Vieira et al., 2005). In the present study, the organ weight ratios were not affected as reported in earlier studies (Chattopadhyay et al., 2011; Collins et al., 2001; Bird et al., 1992). The histopathological changes in the kidney and liver in the high $\mathrm{F}$ groups are following similar studies conducted in rats (KhadarBasha and Jayantha Rao, 2014; Song et al., 2015; Song et al., 2014). In conclusion, the dosedependent effect of $F$ starts at 100, 50 and $15 \mathrm{mg} / \mathrm{L}$ from first, second and third months respectively, however, there were no significant differences in 5 and $10 \mathrm{mg} / \mathrm{L} \mathrm{F}$ groups after 3 months. In the present study, the dose of $F$ concentrations that would cause $F$ toxicity is $15 \mathrm{mg} / \mathrm{L}$ in rats. This toxic dose i.e., 15 $\mathrm{mg} / \mathrm{L}$ in rats would cause plasma $\mathrm{F}$ levels equivalent to those in humans consuming fluoridated water levels of $3 \mathrm{mg} / \mathrm{L}$ (Dunipace et al., 1995). Hence, the present study suggests the human consumption of 3 $\mathrm{mg} / \mathrm{L} \mathrm{F}$ in drinking water might cause $\mathrm{F}$ toxicity in the population.

\section{Declarations}

\section{Acknowledgments}

The authors acknowledge the encouragement and guidance of the Director, ICMR-National Institute of Nutrition, Hyderabad, India. 


\section{Conflict of interest}

The authors declare that they do not have a conflict of interest.

\section{References}

1. Angmar-Mansson B, Whitford GM (1984) Enamel fluorosis related to plasma F levels in the rat. Caries Res 18:25-32

2. Angmar-Mansson B, Whitford GM (1990) Environmental and physiological factors affecting dental fluorosis. J Dent Res 69:706-713

3. Balaji B, Kumar EP, Kumar A (2015) Evaluation of standardized Bacopamonniera extract in sodium fluoride-induced behavioral, biochemical, and histopathological alterations in mice. Toxicol Ind Health 31(1):18-30

4. Bird DM, Carriere D, Lacombe D (1992) The effect of dietary sodium fluoride on internal organs breast muscle and bones in captive American kestrels (Falco sparverius). Arch Environ Contam Toxicol 22:242-246

5. Chattopadhyay A, Podder S, Agarwal S, Bhattacharya S (2011) Fluoride-induced histopathology and synthesis of stress protein in liver and kidney of mice. Arch Toxicol 85(4):327-335

6. Chen J, Cao J, Wang J, Jia R, Xue W, Li Y, Luo Y, Xie L (2013) Effects of fluoride on growth, body composition, and serum biochemical profile in a freshwater teleost, Cyprinuscarpio. Environ Toxicol Chem 32(10):2315-2321

7. Coetze CB, Casey NH, Meyer JA (1997) Fluoride tolerance of laying hens. Br Poult Sci 38:597-602

8. Collins TF, Sprando RL, Black TN, Shackelford ME, Bryant MA, Olejnik N, Ames MJ, Rorie JI, Ruggles DI (2001) Multigenerational evaluation of sodium fluoride in rats. Food ChemToxicol 39(6):601-613

9. CorreiaSampaio F, von der Ramm F, Arneberg P, PetrucciGigante D, Hatloy A (1999) Dental fluorosis and nutritional status of 6- to 11-year old children living in rural areas of Paraiba, Brazil. Caries Res 33:66-73

10. Del Carmen AF, Javier FH, Aline CC (2016) Dental fluorosis, fluoride in urine, and nutritional status in adolescent students living in the rural areas of Guanajuato, Mexico. J Int Soc Prev Community Dent 6(6):517-522

11. Dunipace AJ, Brizendine EJ, Zhang W, Wilson ME, Miller LL, Katz BP, Warrick JM, Stookey GK (1995) Effect of Aging on Animal Response to Chronic Fluoride Exposure. J Dent Res 74(1):358-368

12. Dunipace AJ, Edward JB, Wilson ME, Zhang W, Katz BP, Stookey GK (1998) Chronic fluoride exposure does not cause detrimental, extra skeletal effects in nutritionally deficient rats. J Nutr 128:13921400

13. Hong F, Zheng C, Xu DG, Qian YL (2013) Chronic combined effects of fluoride and arsenite on the Runx2 and downstream related factors of bone metabolism in rats. Zhonghua Yu Fang Yi Xue Za Zhi 47(9):794-798 
14. Huang MC, Chao A, Kirwan R, Tschanz C, Peralta JM, Diersen-Schade DA et al (2002) Negligible changes in piglet serum clinical indicators or organ weights due to dietary single-cell long chain polyunsaturated oils. Food Chem Toxicol 40:453-460

15. Inkielewicz Krechniak J (2003) Fluoride content in soft tissues and urine of rats exposed to sodium fluoride in drinking water. Fluoride 36(4):263-266

16. Irigoyen-Camacho ME, García Pérez A, Mejía González A, Huizar Alvarez R (2016) Nutritional status and dental fluorosis among schoolchildren in communities with different drinking water fluoride concentrations in a central region in Mexico. Sci Total Environ 541:512-519

17. KhadarBasha S, Jayantha Rao K (2014) Sodium fluoride induced histopathalogical changes in liver and kidney of albino mice. Acta Chim Pharm Indica 4(1):58-62

18. Khandare AL, Kumar PU, Lakshmaiah N (2001) Fluoride toxicity-Dietary intervention, vol 22. National Institute of Nutrition, Hyderabad, 1

19. Khandare AL, Kumar PU, Shankar HN, Kalyanasundaram S, Shanker Rao G (2007) Effect of calcium deficiency induced by fluoride intoxication on lipid metabolism in rabbits. Fluoride 40:184-189

20. Liu L, Zhang Y, Gu HF, Zhang KQ, Ma L, Cheng RB, Zhang SY (2014) The effect of fluoride on the metabolism of teeth and bone in rats. Shanghai Kou Qiang Yi Xue 23(2):129-132

21. Lohakare J, Pattanaik A, Khan SA (2010) Effect of long-term fluoride exposure on growth, nutrient utilization and fluoride kinetics of calves fed graded levels of dietary protein. Biol Trace Elem Res 138:148-162

22. Pereira HA, Leite Ade L, Charone S, Lobo JG, Cestari TM, Peres-Buzalaf C, Buzalaf MA (2013) Proteomic analysis of liver in rats chronically exposed to fluoride. PLoS ONE 8(9):e75343

23. Rugg-Gunn AJ, al-Mohammadi SM, Butler TJ (1997) Effects of fluoride level in drinking water, nutritional status, and socio-economic status on the prevalence of developmental defects of dental enamel in permanent teeth in Saudi 14-year-old boys. Caries Res 31(4):259-267

24. Saxena KL, Sewak R (2015) Fluoride consumption in endemic villages of India and its remedial measures. Int J Eng Sci Invent 4(1):58-73

25. Shankar P, Ghosh S, Bhaskarachary K, Venkaiah K, Khandare AL (2013) Amelioration of chronic fluoride toxicity by calcium and fluoride-free water in rats. Br J Nutr 110(1):95-104

26. Shanthakumari D, Srinivasalu S, Subramanian S (2004) Effects of fluoride intoxication on lipid peroxidation and antioxidant status in experimental rats. Toxicology 204:219-228

27. Singer L, Armstrong WD (1968) Determination of fluoride in bone with the fluoride electrode. Anal Chem 40:613-614

28. Song GH, Gao JP, Wang CF, Chen CY, Yan XY, Guo M, Wang Y, Huang FB (2014) Sodium fluoride induces apoptosis in the kidney of rats through caspase-mediated pathways and DNA damage. $J$ Physiol Biochem 70(3):857-868

29. Song GH, Huang FB, Gao JP, Liu ML, Pang WB, Li WB, Yan XY, Huo MJ, Yang X (2015) Effects of fluoride on DNA damage and caspase-mediated apoptosis in the liver of rats. Biol Trace Elem Res 
166(2):173-182

30. Susheela AK, Bhatnagar M (2002) Reversal of fluoride induced cell injury through elimination of fluoride and consumption of diet rich in essential nutrients and antioxidants. Mol Cell Biochem 234235(1-2):335-340

31. Turner CH, Garetto LP, Dunipace AJ, Zhang W, Wilson ME, Grynpas MD, Chachra D, McClintock R, Peacock M, Stookey GK (1997) Fluoride treatment increased serum IGF-1, bone turnover, and bone mass but not bone strength in rabbits. Calcif Tissue Int 61:77-83

32. Tusl J (1970) Direct measurement of fluoride in human urine using fluoride electrode. Clin Chem Acta 27(1):216-218

33. Vieira AP, Mousny M, Maia R, Hancock R, Everett ET, Grynpas MD (2005) Assessment of teeth as biomarkers for skeletal fluoride exposure. Osteoporos Int 16(12):1576-1582

34. Wang LF, Huang JZ (1995) Outline of control practice of endemic fluorosis in China. Soc Sci Med 41(8):1191-1195

35. Watanabe T, Kondo T, Asanuma S, Sakurai S, Tamura K, Ando M (1997) Endemic fluorosis in southern China: radiological findings. Nihon Igaku Hōshasen Gakkai Zasshi Nippon Acta Radiol 57(7):425-426

36. Wei ZD (2002) Fluoridation in China: a clouded future. Fluoride 35(1):1-4

37. World Health Organization (2003) Background Document for Preparation of WHO Guidelines for Drinking water Quality. Fluoride in Drinking-water. Geneva: WHO. http://www.who.int/water_sanitation_health/dwq/chemicals/ fluoride.pdf

38. World Health Organization (2004) W.H.O. Chemical aspects. W.H.O. Guidelines for drinking-water quality volume 1 In, W.H.O; pp. 3rd ed. Geneva: 184-186

39. Song Yu-e, Tan H, Liu Ke-jian, Zhang Yu-zeng, Liu Y, Lu Cui-rong, Cai-yanCui (2011) Da-lin Yu, Jun Tu, Effect of fluoride exposure on bone metabolism indicators ALP, BALP and BGP. Environ Health Prev Med 16:158-163

40. Zhang Y, Zhang Y, Zheng X, Xu R, He H, Duan X (2016) Grading and quantification of dental fluorosis in zebra fish larva. Arch Oral Biol 70:16-23

\section{Figures}




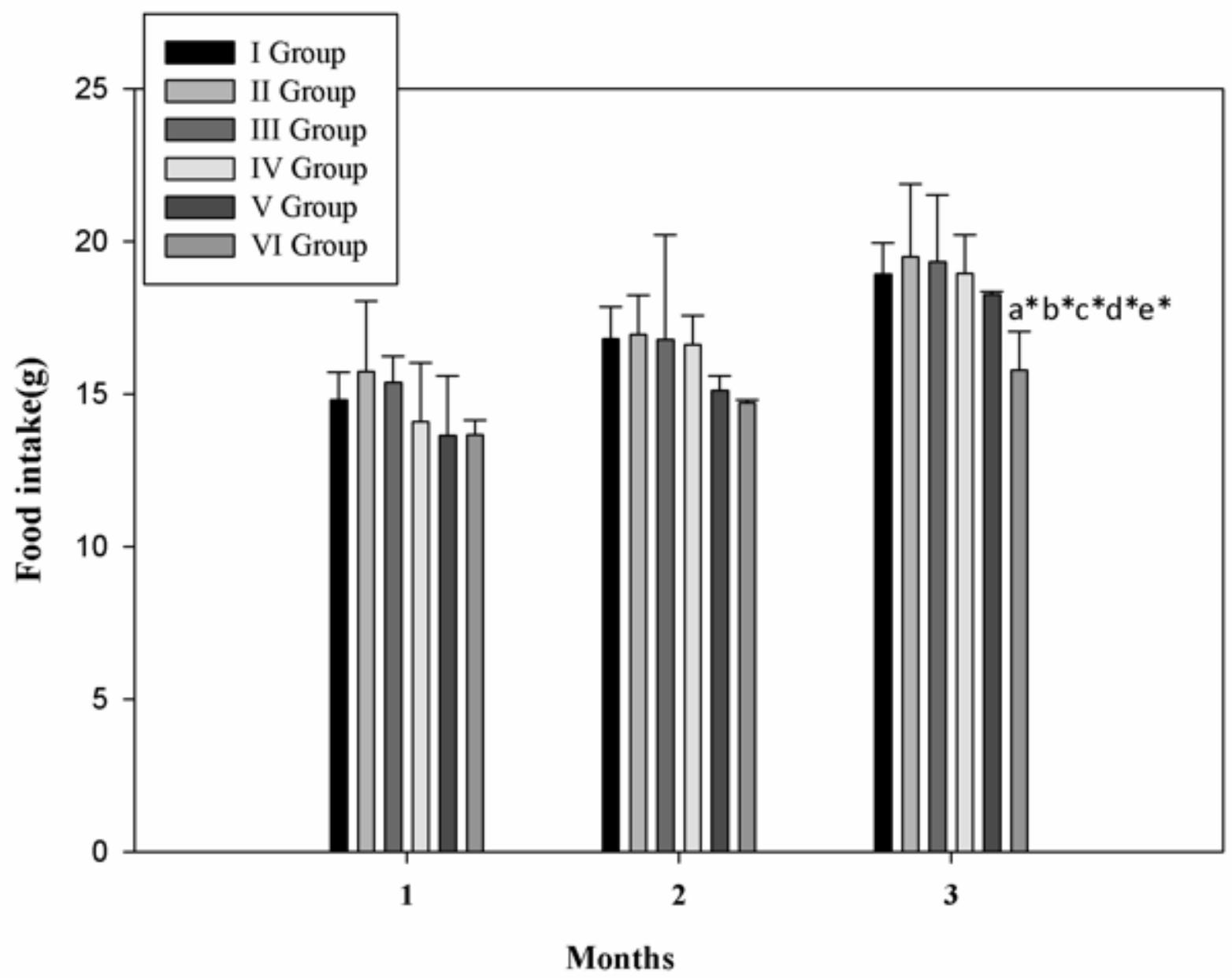

Figure 1

Food intake by rats of different groups at 1, 2 and 3 months. * Statistically significant $(p<0.05)$. $a=$ compared to group I, b=compared to group II, c=compared to group III, d=compared to group IV, $\mathrm{e}=$ compared to group $\mathrm{V}$. Results are expressed as mean $\pm S D ; n=6$ rats/group. 


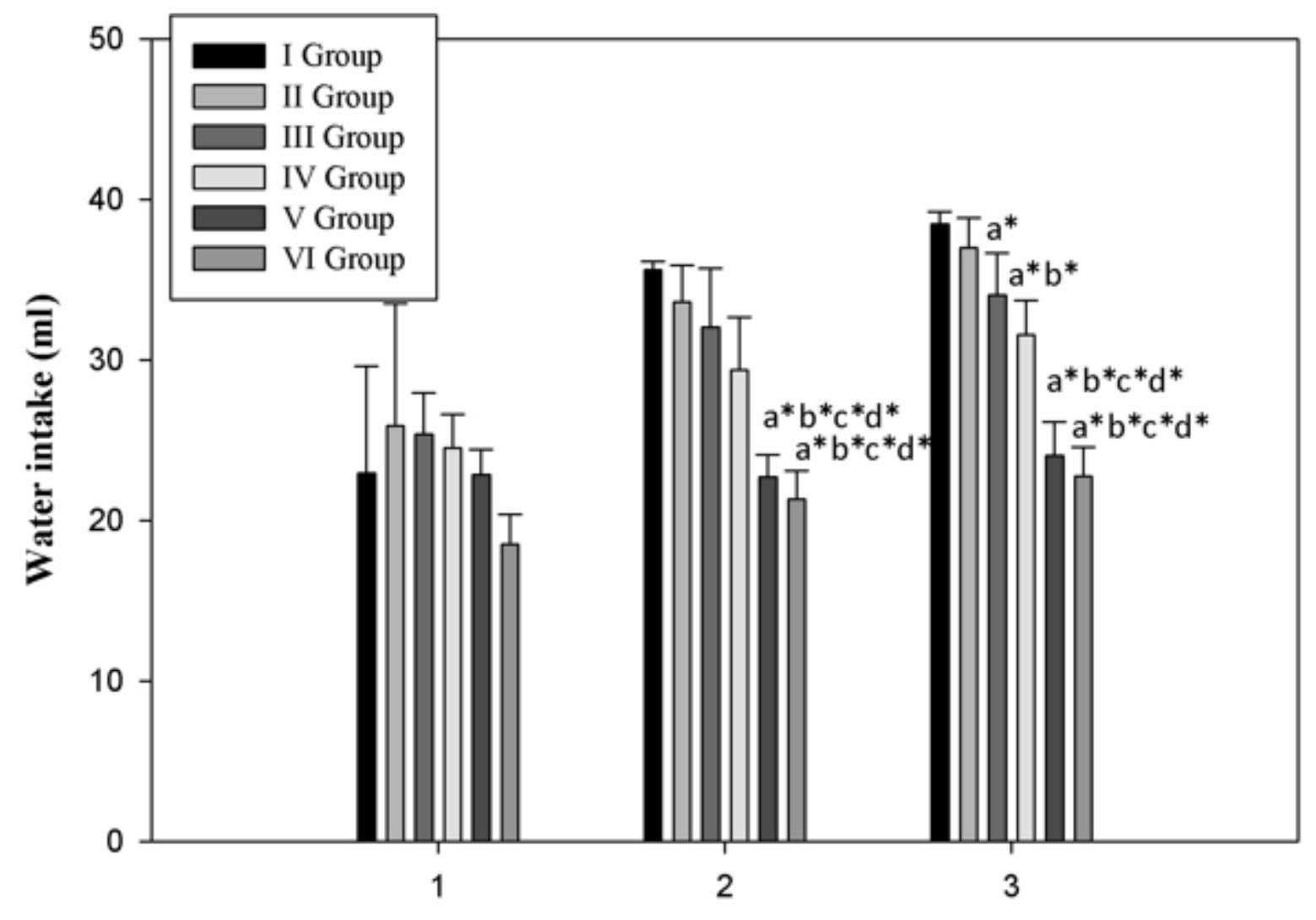

Months

Figure 2

Water intake by rats of different groups at 1,2 and 3 months. *Statistically significant $(p<0.05)$. $a=$ compared to group I, b=compared to group II, c=compared to group III, d=compared to group IV, $\mathrm{e}=$ compared to group $\mathrm{V}$. Results are expressed as mean $\pm S D ; n=6$ rats/group. 


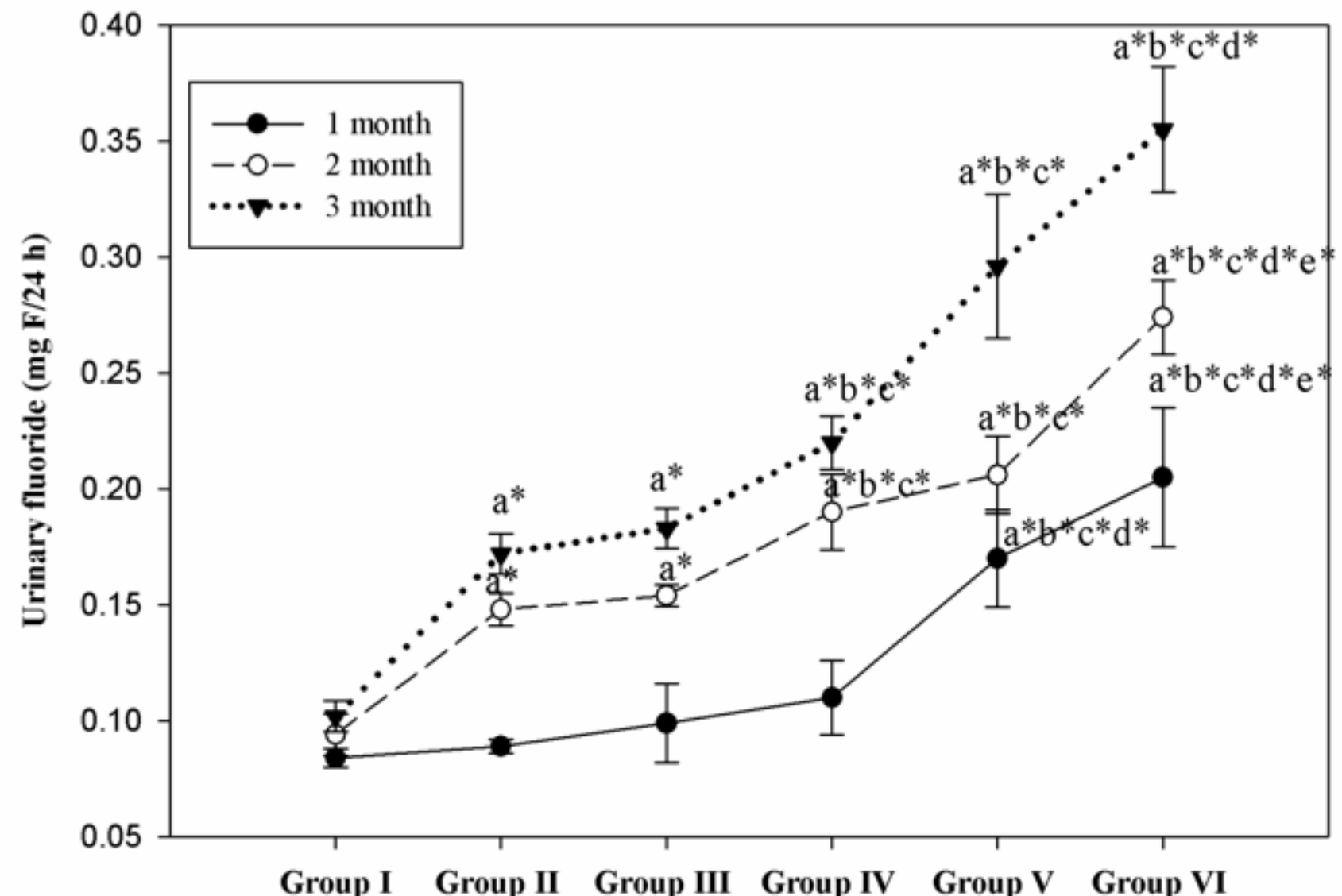

Figure 3

Urinary fluoride ( $\mathrm{mg} \mathrm{F} / 24 \mathrm{hr}$ ) levels in different groups at 1, 2 and 3 months. *Statistically significant $(p<0.05)$. a=compared to group I, b=compared to group II, $c=$ compared to group III, $d=$ compared to group IV, e=compared to group V. Results are expressed as mean $\pm S D ; n=6$ rats/group. 


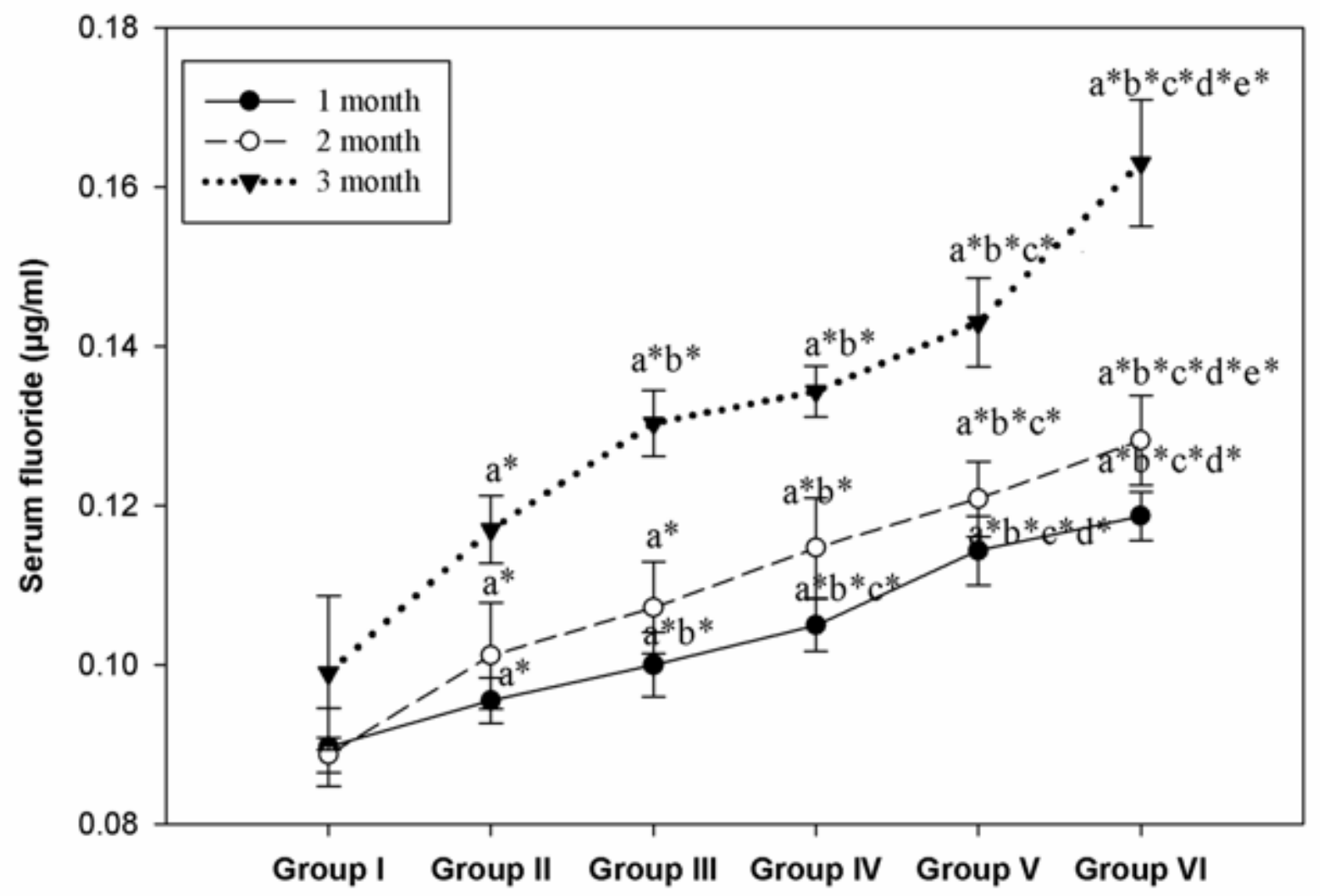

Figure 4

Serum fluoride $(\mu \mathrm{g} / \mathrm{ml})$ levels in different groups at 1,2 and 3 months. ${ }^{*}$ Statistically significant $(p<0.05)$. $a=$ compared to group I, b=compared to group II, c=compared to group III, d=compared to group IV, $\mathrm{e}=$ compared to group $\mathrm{V}$. Results are expressed as mean $\pm S D ; n=6$ rats/group. 


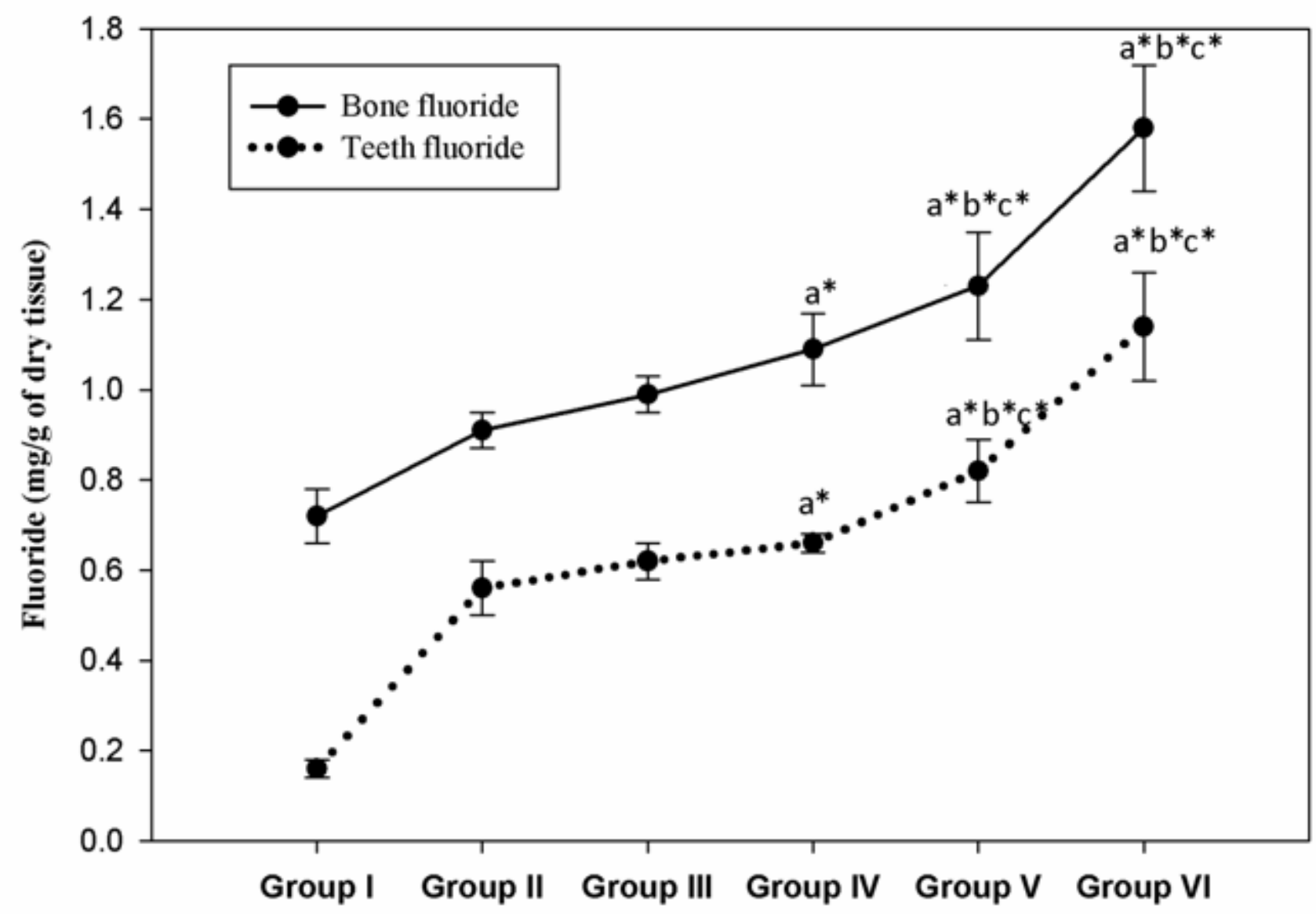

Figure 5

Bone and teeth fluoride levels in the different groups at 3 months. * Statistically significant $(p<0.05)$. $\mathrm{a}=$ compared to group I, b=compared to group II, c=compared to group III. Results are expressed as mean $\pm S D ; n=6$ rats/group. 


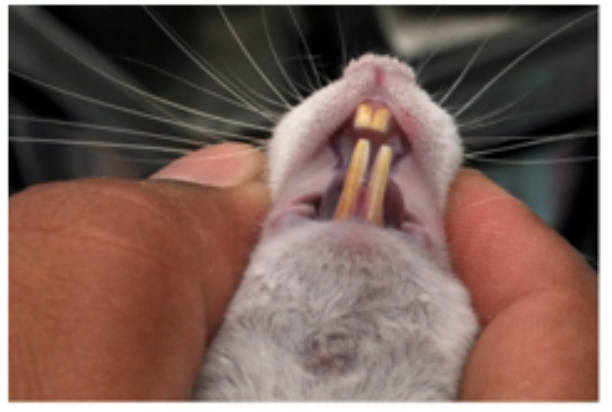

Group I (Control)

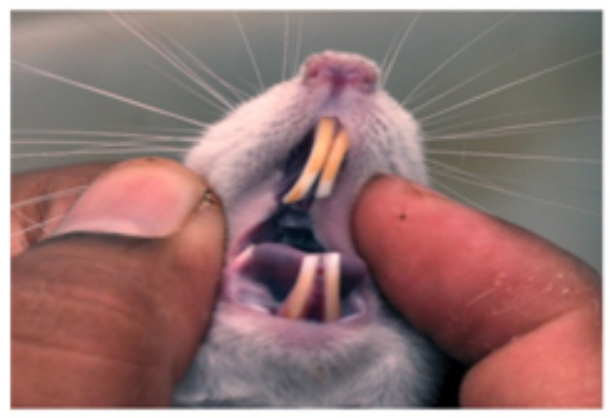

Group IV (15 ppm F)

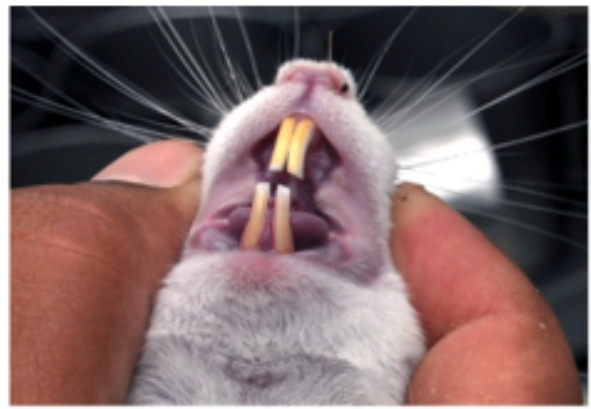

Group II (5 ppm F)

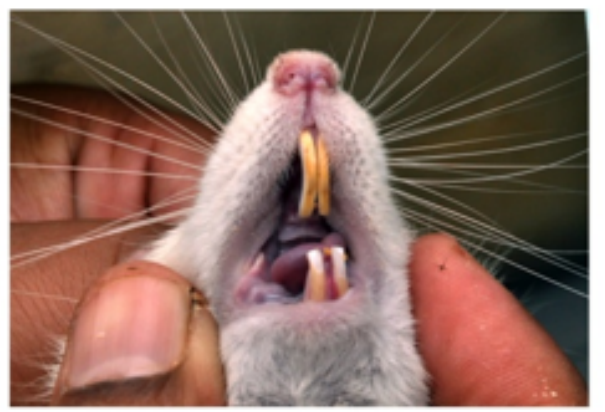

Group V (50 ppm F)

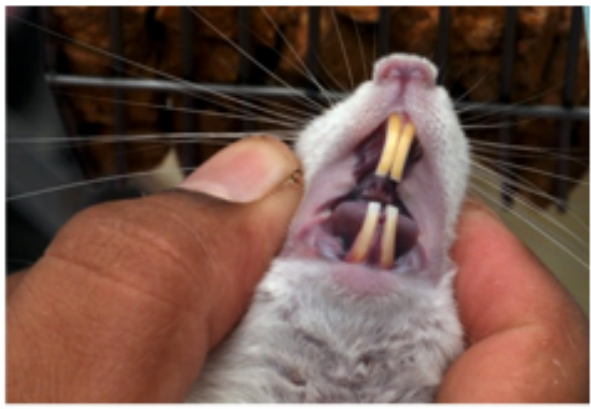

Group III (10 ppm F)

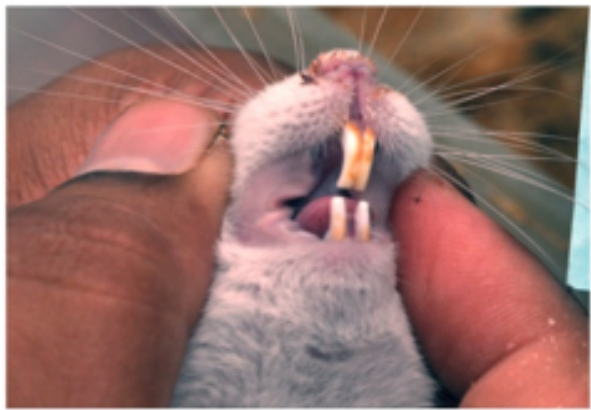

Group VI (100 ppm F)

Figure 6

Dental fluorosis in rats at 3 months in different groups. 


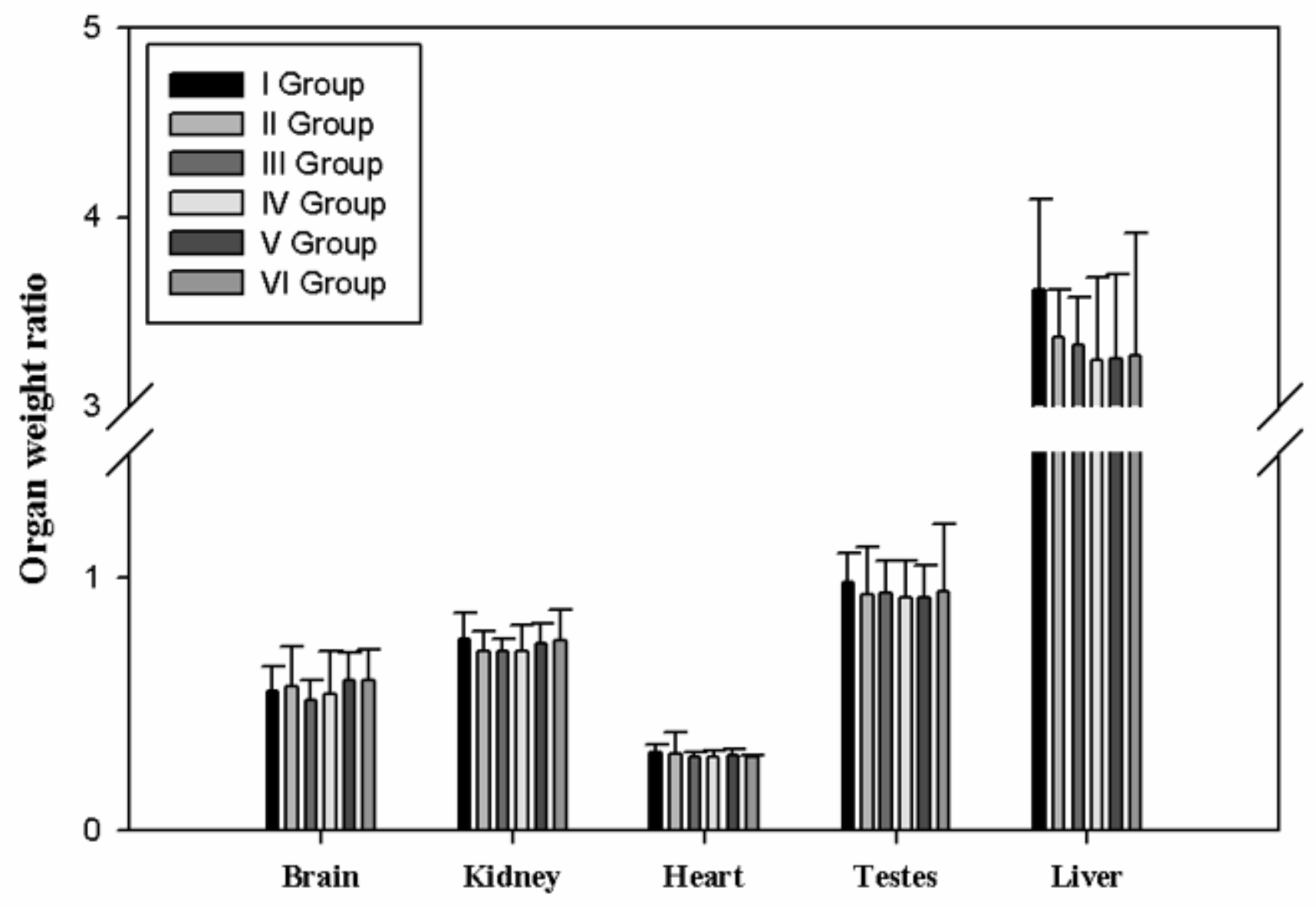

Figure 7

The organ weight ratio of brain, kidney, heart, testes, liver among different groups at 3 months. 

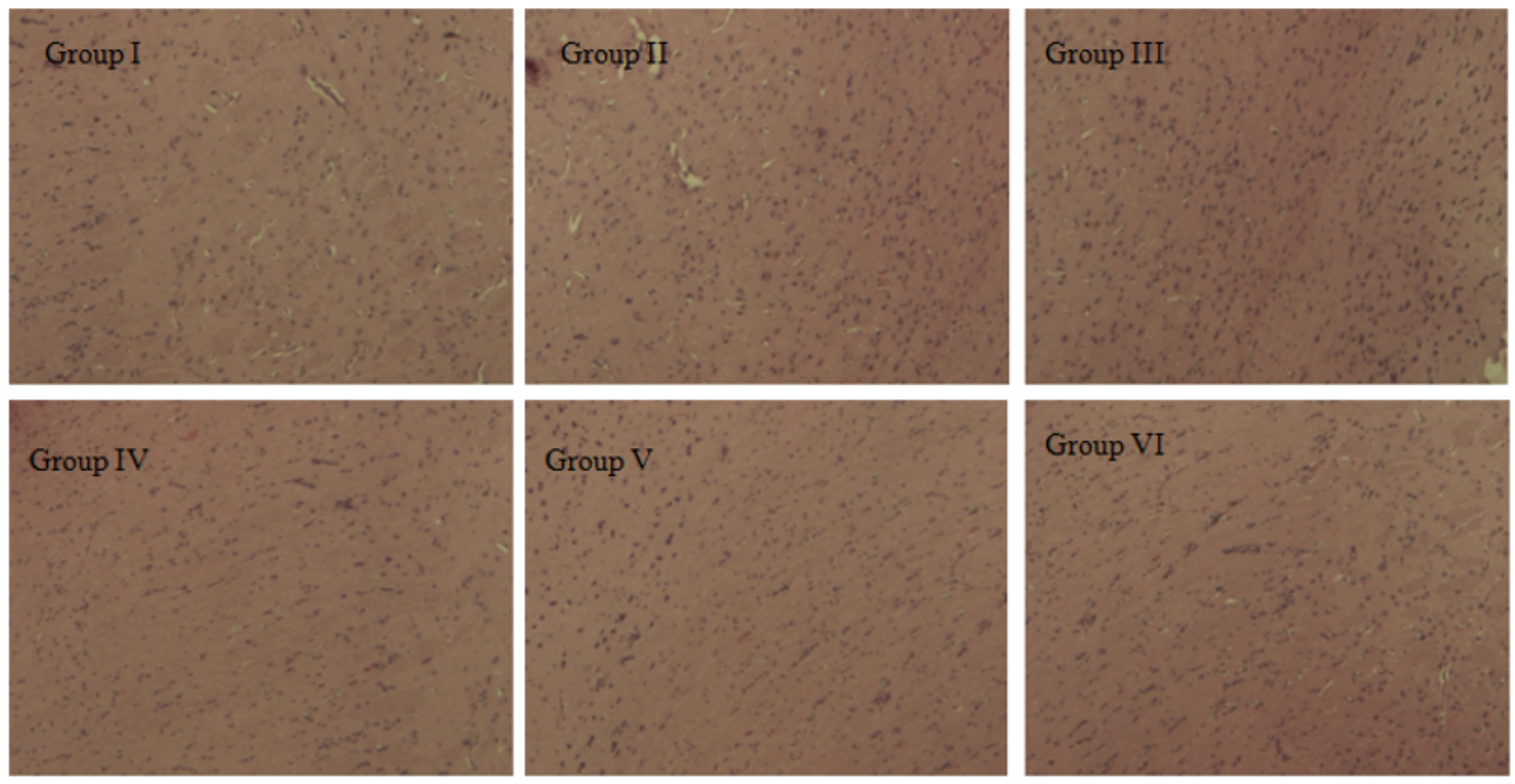

\section{Figure 8}

Histopathology (H\&E) staining of brain (10X) from rat exposed to different fluoride doses for 3 months. 

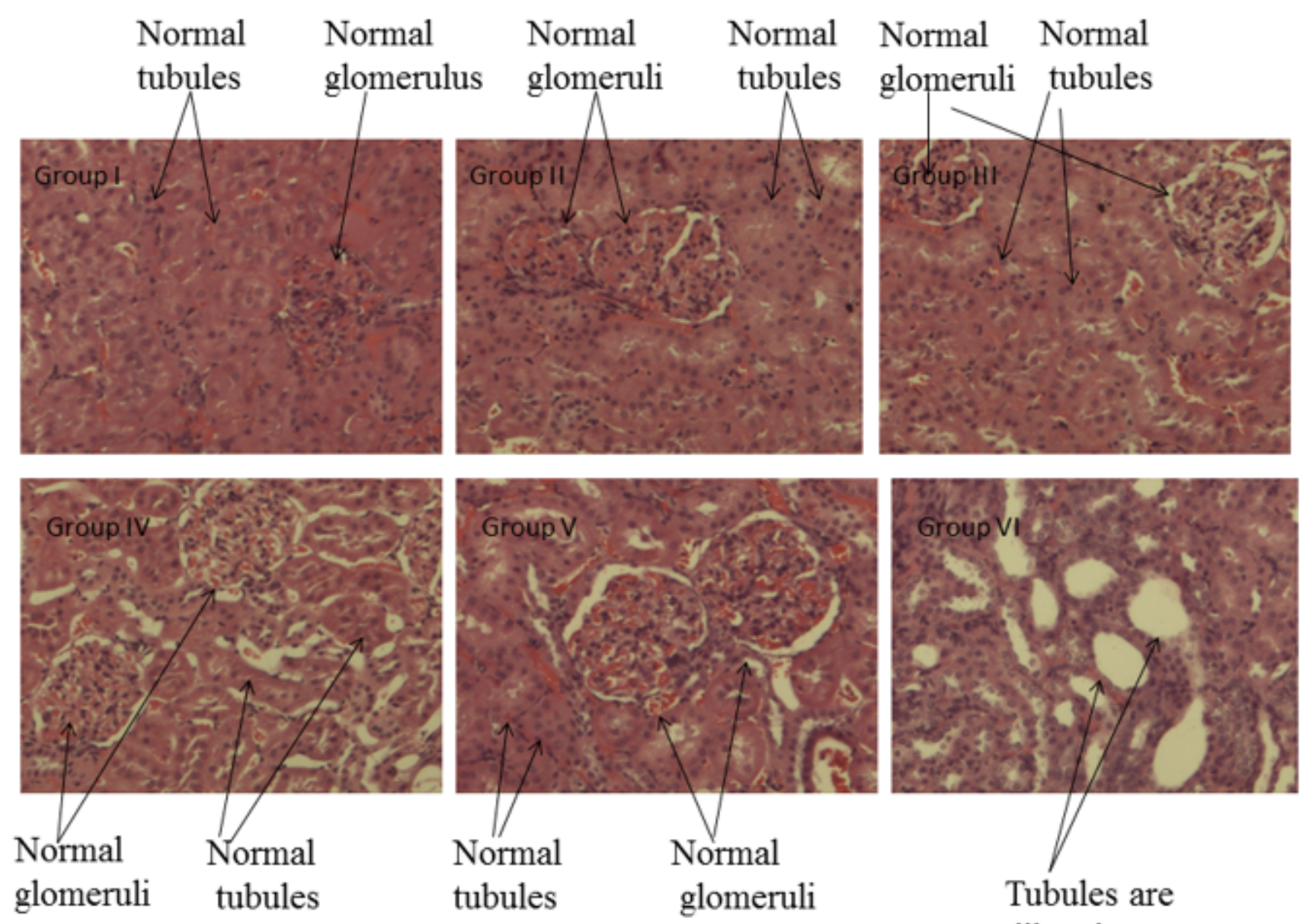

Tubules are dilated

\section{Figure 9}

Histopathology (H\&E) staining of kidney (10X) from rat exposed to different fluoride doses for 3 months. 


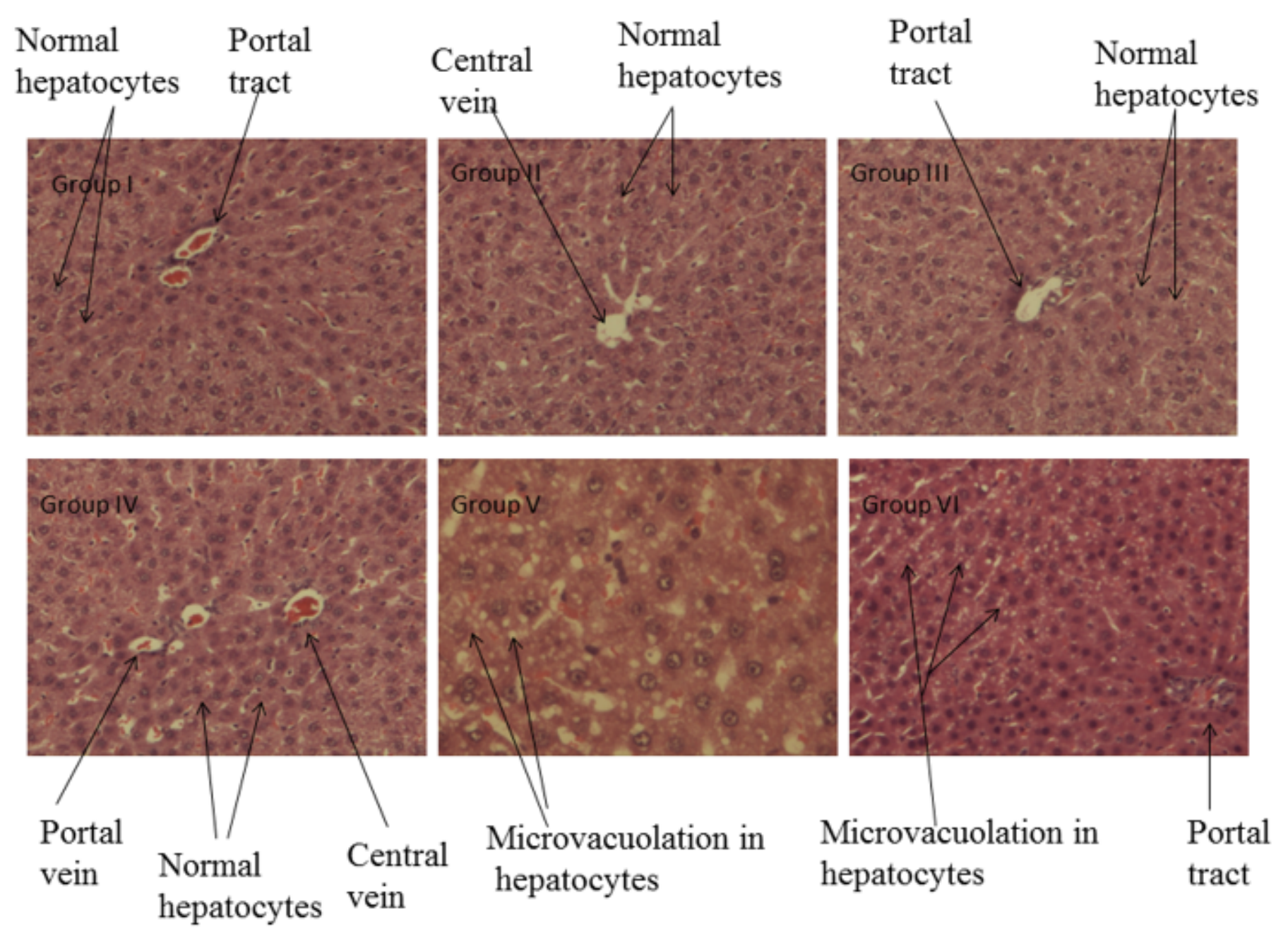

Figure 10

Histopathology of liver (H\&E staining ) (10X) of rat exposed to different fluoride doses for 3 months. 